\title{
Present Scenario Regarding Vocational Interest between the Genders
}

\author{
Amita Srivastava $^{1} *$
}

\section{ABSTRACT}

This study examines the gender differences in selection of the vocational choices amongst the students aged between 17 to 22 years. A sample of 120 students, 60 boys \& 60 girls, was studied for this purpose. Vocational interest record developed was used for determination of the vocational interest with respect to gender. It is discerned that boys have high interest in scientific, constructive and agricultural vocations than the girls.

Keywords: Gender, Vocational Interest

The term 'Gender' represents the society beliefs about the traits and behavior of males and females. Gender identity, the awareness of one's femaleness and maleness, is an aspect of the developing self-concept (Papalia, 2004). Gender identity is established quite early in life. In Indian traditional culture, roles of male and female are decided at the time of birth.

However, according to Kohlberg (1966) children cannot maintain the constancy of their gender before the age of 6 or 7 years. During the late preschool and early school years, children understand that sex is biologically based (Emmerich, 1981, Ruble et al., 2007). According to gender schema theory (Bem, 1984, 1989), children develop a cognitive framework reflecting the beliefs of their society, about the characteristics and roles of males and females. Once a gender schema forms, it influences children's processing of many kinds of social information (Martin \& Little, 1990). Sex-role adjustment is fundamental to vocational adjustment. A male cannot be satisfied with a masculine job that he selects because of parental pressure or social pressure because his real interest lies in a vocation that is regarded as "feminine". Similarly women, accustomed during their school and college days to playing egalitarian roles with their male peers, find it hard to adjust to the treatment they receive in Industry and business. Boys typically want glamorous and exciting jobs with high prestige. Girls, prefer those occupations which provide them greater security and less demand on their time. They usually prefer those vocations

\footnotetext{
${ }^{1}$ Head, Department of Home Science, Methodist Girls Post Graduate College, Civil Lines, Roorkee. Uttarakhand. *Responding Author

(C) 2016, A Srivastava; licensee IJIP. This is an Open Access Research distributed under the terms of the Creative Commons Attribution License (http://creativecommons.org/licenses/by/2.0), which permits unrestricted use, distribution, and reproduction in any Medium, provided the original work is properly cited.
} 


\section{Present Scenario Regarding Vocational Interest between the Genders}

which are regarded as service to others, such as teaching or nursing. Gender constancy and cognitive changes are basically responsible for gender role adoption. Understanding of gender stability prompts increased gender stereotyping (Martin \& Little, 1990; Ruble et.al., 2007).

Vocation refers to a strong feeling for doing a particular job. Selection of a vocation is becoming increasingly difficult in successive generation of young adults because of the increase in kinds of jobs and choice (Hurlock, 2011). During the adolescent and early adulthood period, students of both the gender are quiet confused about their career goals. Self-efficacy plays an important role in success and satisfaction in the vocation. At least, ninety five percent of all teenagers are disappointed in their vocational choice (Srivastava, 2015). It is discerned that if a person involves in his preferred vocation, his dedication towards the job is high \& he is more satisfied and happy in life. This impacts development of personality and a healthy and happy society. There is however a lack of systematic study is on vocational interest of the girls and boys of the Haridwar district, Uttarakhand state, India. This study determines the difference in vocational interest of boys and girls age between 17 to 22 years, in Haridwar district.

\section{Hypothesis:}

There is no significant difference in the vocational interests such as literacy, Scientific, Executive, Commercial, Constructive, Artistic, Agriculture, Persuasive, Social and Household vocation between boys $\&$ girls aged between 17 to 22 years.

\section{Sample:}

A sample of 120 boys \& girls ranging between ages of 17 to 22 years, from Haridwar District, Uttarakhand, was selected for this study. Out of 120 students, 60 girls \& 60 boys were taken. Stratified random sampling technique was used for the selection of the sample.

\section{Tool:}

Vocational Interest record (VIR) developed by Kulshrestha (1977) is used. The test is developed for measuring the interest of the individual, so that the person can adjust to the career / Job accordingly. The main purpose of VIR is to measure vocational interest in order to enable students in selecting such subjects in intermediate and undergraduate level which are according to their preferred areas such as, Literary, Scientific, Executive, Commercial, Constructive, Artistic, Agriculture, Persuasive, Social and Household.

\section{Procedure:}

Data were collected from various Intermediate \& Degree colleges of Haridwar district, Uttarakhand, India. Test administration was conducted in group setting in a single session during school hours. The measures were administered to the students with proper instructions. Students took about 40 minutes to complete the scale. Whenever they had any doubt in the understanding a question, the researcher made it clarified it. 


\section{Present Scenario Regarding Vocational Interest between the Genders}

\section{Analysis:}

The data obtained were subjected to statistical analysis such as percentage tables, contingency tables and Chi-square test was used to test the hypothesis. The interpretation is made as per the guidelines of the manual of Vocational interest record (Kulshrestha, 1977). The level of confidence adopted in this study is 0.05 .

\section{RESULTS}

Literary: Literary is concerned or connected with the writing, study or appreciation of literature. Table No. 1. Reveals $X^{2}=4.06$, $d f=2$, significant at 0.05 level of confidence. $P$ lies at 0.10 and this suggests that the gender of the students does not significantly affect the vocational choice of Literary jobs.

Scientific: The term 'Scientific' relates to science. In the case of boys and girls, there is a significant difference of vocational choice of Scientific interest. As compared to girls, boys are more interested in the scientific jobs. As shown in the percentage Table No. 2, 26.66\% boys showed high interest in the scientific jobs against $8.33 \%$ girls. Table 2 also reveals that gender has a significant effect on the choice of scientific jobs. $X^{2}=7.38$, $\mathrm{df}=2$, $\mathrm{P}$ lies between $0.05-$ 0.02. Therefore the null hypothesis has been rejected.

Executive: An 'Executive' is someone who is employed at a senior level and makes decisions to get the works done. The Executive decides what business is to be done and ensures that the job is executed properly. Table 3 shows those $40 \%$ girls and $43.33 \%$ boys are highly interested in vocation like 'Executive'. Our results indicate that boys \& girls both are interested in executive jobs in almost equal ratio. $X^{2}=3.44$, $\mathrm{df}=2$, significant at 0.05 level of confidence. Therefore the null hypothesis could not be rejected.

Commercial: 'Commercial' means involving or relating to buying and selling of goods. Commercial organizations and activities are concerned with making profits. In Table 4, the value of $X^{2}$ is 1.3 , df $=2$ significant at 0.05 level of confidence. This reveals that there is no significant difference in vocational interest of commercial jobs between boys and girls. Therefore the null hypothesis is accepted.

Constructive: 'Constructive' jobs include vocations like Goldsmith, Ironsmith, Radio/T.V. mechanics, Book binder and Toy maker. Table 5 reveals that $X^{2}=8.56, \mathrm{df}=2$, significant at 0.01 level of confidence. Therefore the null hypothesis has been rejected. Our results indicate that boys are more interested in the constructive jobs as compared to girls.

Artistic: 'Artistic' means relating to art or arranging things in a beautiful way. Artistic jobs are such as Singer, Music director, Painter, Cartoonist, Photographer and Dancer. Table 6 reveals $X^{2}$ 


\section{Present Scenario Regarding Vocational Interest between the Genders}

$=5.68, \mathrm{df}=2$, significant at 0.05 level of confidence. Only $20 \%$ girls and $10 \%$ boys express their high interest in artistic jobs. Therefore the null hypothesis could not be rejected.

Agriculture: 'Agriculture' means involving or relating to agriculture. This area includes assignments such as Gardner, Farmer, Animal Husbandry, Agriculture Inspector, Agriculture teacher, Horticulturist, Dairy man etc. In the comparison between boys and girls, we found a significant difference of opinion regarding agriculture jobs. Table 7 shows the value of is $X^{2}=$ 25.06, $\mathrm{df}=2$, significant at 0.01 level of confidence. Therefore the null hypothesis has been rejected. This reveals that the gender makes a significant difference of vocational choice like Agriculture. Here, boys are more interested in Agricultural vocation than girls.

Persuasive: 'Persuasive' is someone who persuades someone else to do or believe a particular thing such as Advertisement manager, MP/MLA, Insurance agent, Vocational counselor, Advocate or Sales manager etc. Table No.8 shows the value of $X^{2}=1.04$, $\mathrm{df}=2$, significant at 0.05 level of confidence. Our results reveals that $12 \%$ girls and $18 \%$ boy shows high interest in Persuasive jobs and $55 \%$ girls and 52\% boy shows their moderate interest in Persuasive jobs. Therefore the null hypothesis could not be rejected.

Social: 'Social' means relating to society or to the way society is organized. Following jobs are come under the social jobs namely: Scouts and guide, Religious reformer, Red Cross worker, Free medicine distributor, Guide, Social worker etc. Table 9 reveals that $X^{2}=4.4$, $\mathrm{df}=2$, significant at 0.05 level of confidence. Therefore the null hypothesis could not be rejected. It implies that there is no significant difference of vocational interest in social jobs.

Household: The term 'Household' implies relation to people living in the home or house. Jobs like Home Science Teacher, Home Science Researcher, Nurse, Home Manager, Expert in cooking, Home Decorator or Interior decorator is included under this category. Table 10 reveals that $X^{2}=4.74, \mathrm{df}=2$, significant at 0.05 level of confidence. Our results indicate that both boys and girls have similar interest in the vocational choice Household. Therefore the null hypothesis could not be rejected.

\section{CONCLUSION}

The present study is to investigate whether the vocational choice differs with respect to gender. Results clearly show that the gender of the students does not affect the vocational interest towards Literature, Executive jobs, Commercial jobs, Persuasive jobs, Artistic jobs, Social Jobs and Household jobs. Our findings also reveal that boys, in comparison to girls, are highly interested in vocations like Scientific, Constructive and Agriculture vocations. (Fig. No.11, 12, 13). 
Present Scenario Regarding Vocational Interest between the Genders

Percentage Table No. 1 (Literary)

\begin{tabular}{|l|l|l|l|}
\hline Students & High & Moderate & Low \\
\hline Girls & $3.33 \%$ & $33.33 \%$ & $63.33 \%$ \\
\hline Boys & $5 \%$ & $50 \%$ & $45 \%$ \\
\hline
\end{tabular}

Contingency Table No. 1

\begin{tabular}{|l|l|l|l|l|}
\hline Students & High & Moderate & Low & Total \\
\hline Girls & $2(2.5)$ & $20(25)$ & $38(32.5)$ & 60 \\
\hline Boys & $3(2.5)$ & $30(25)$ & $27(32.5)$ & 60 \\
\hline Total & 5 & 50 & 65 & 120 \\
\hline
\end{tabular}

$X^{2}=4.06: \mathrm{df}=2$

Significant at 0.05 level of confidence

Percentage Table No. 2. (Scientific)

\begin{tabular}{|l|l|l|l|}
\hline Students & High & Moderate & Low \\
\hline Girls & $8.33 \%$ & $60 \%$ & $31.66 \%$ \\
\hline Boys & $26.66 \%$ & $43.33 \%$ & $30 \%$ \\
\hline
\end{tabular}

Contingency Table No. 2

\begin{tabular}{|l|l|l|l|l|}
\hline Students & High & Moderate & Low & Total \\
\hline Girls & $5(10.5)$ & $36(31)$ & $19(18.5)$ & 60 \\
\hline Boys & $16(10.5)$ & $26(31)$ & $18(18.5)$ & 60 \\
\hline Total & 21 & 62 & 37 & 120 \\
\hline
\end{tabular}

$X^{2}=7.38^{*}: \mathrm{df}=2$

Significant at 0.01 level of confidence

Percentage Table No. 3. (Executive)

\begin{tabular}{|l|l|l|l|}
\hline Students & High & Moderate & Low \\
\hline Girls & $40 \%$ & $35 \%$ & $25 \%$ \\
\hline Boys & $43.33 \%$ & $43.33 \%$ & $13.33 \%$ \\
\hline
\end{tabular}

Contingency Table No. 3 (Executive)

\begin{tabular}{|l|l|l|l|l|}
\hline Students & High & Moderate & Low & Total \\
\hline Girls & $24(25)$ & $21(23.5)$ & $15(11.5)$ & 60 \\
\hline Boys & $26(25)$ & $26(23.5)$ & $8(11.5)$ & 60 \\
\hline Total & 50 & 47 & 23 & 120 \\
\hline
\end{tabular}

$X^{2}=3.44: \mathrm{df}=2$

Significant at 0.05 level of confidence

Percentage Table No. 4. (Commercial)

\begin{tabular}{|l|l|l|l|}
\hline Students & High & Moderate & Low \\
\hline Girls & $1.6 \%$ & $41.66 \%$ & $56.66 \%$ \\
\hline Boys & $5 \%$ & $45 \%$ & $50 \%$ \\
\hline
\end{tabular}

(C) The International Journal of Indian Psychology, ISSN 2348-5396 (e)| ISSN: 2349-3429 (p) | 17 
Present Scenario Regarding Vocational Interest between the Genders

Contingency Table No. 4 (Commercial)

\begin{tabular}{|l|l|l|l|l|}
\hline Students & High & Moderate & Low & Total \\
\hline Girls & $1(2)$ & $25(26)$ & $34(32)$ & 60 \\
\hline Boys & $3(2)$ & $27(26)$ & $30(32)$ & 60 \\
\hline Total & 4 & 52 & 64 & 120 \\
\hline$X^{2}$ & & 64 & (2) \\
\hline
\end{tabular}

$X^{2}=1.3: \mathrm{df}=2$

Significant at 0.05 level of confidence

Percentage Table No. 5 (Constructive)

\begin{tabular}{|l|l|l|l|}
\hline Students & High & Moderate & Low \\
\hline Girls & $0 \%$ & $5 \%$ & $95 \%$ \\
\hline Boys & $3.33 \%$ & $20 \%$ & $76.66 \%$ \\
\hline
\end{tabular}

Contingency Table No. 5

\begin{tabular}{|l|l|l|l|l|}
\hline Students & High & Moderate & Low & Total \\
\hline Girls & $0(1)$ & $3(7.5)$ & $57(51.5)$ & 60 \\
\hline Boys & $2(1)$ & $12(7.5)$ & $46(51.5)$ & 60 \\
\hline Total & 2 & 15 & 103 & 120 \\
\hline
\end{tabular}

$X^{2}=8.56^{*}: \mathrm{df}=2$

Significant at 0.01 level of confidence.

Percentage Table No. 6. (Artist)

\begin{tabular}{|l|l|l|l|}
\hline Students & High & Moderate & Low \\
\hline Girls & $20 \%$ & $48.33 \%$ & $31.66 \%$ \\
\hline Boys & $10 \%$ & $51.66 \%$ & $38.33 \%$ \\
\hline
\end{tabular}

Contingency Table No.6 (Artistic)

\begin{tabular}{|l|l|l|l|l|}
\hline Students & High & Moderate & Low & Total \\
\hline Girls & $12(9)$ & $29(30)$ & $19(16)$ & 60 \\
\hline Boys & $6(9)$ & $31(30)$ & $23(16)$ & 60 \\
\hline Total & 18 & 60 & 32 & 120 \\
\hline
\end{tabular}

$X^{2}=5.68: \mathrm{df}=2$

Significant at 0.05 level of confidence

Percentage Table No. 7 (Agriculture)

\begin{tabular}{|l|l|l|l|}
\hline Students & High & Moderate & Low \\
\hline Girls & $0 \%$ & $13.33 \%$ & $86.66 \%$ \\
\hline Boys & $3.33 \%$ & $53.33 \%$ & $43.33 \%$ \\
\hline
\end{tabular}

Contingency Table No. 7 (Agriculture)

\begin{tabular}{|l|l|l|l|l|}
\hline Students & High & Moderate & Low & Total \\
\hline Girls & $0(1)$ & $8(20)$ & $52(39)$ & 60 \\
\hline Boys & $2(1)$ & $32(20)$ & $26(39)$ & 60 \\
\hline Total & 2 & 40 & 78 & 120 \\
\hline
\end{tabular}

$X^{2}=25.06^{*}, \mathrm{df}=2$

Significant at 0.01 level of confidence

(C) The International Journal of Indian Psychology, ISSN 2348-5396 (e)| ISSN: 2349-3429 (p) | 18 
Present Scenario Regarding Vocational Interest between the Genders

Percentage Table No. 8 (Persuasive)

\begin{tabular}{|l|l|l|l|}
\hline Students & High & Moderate & Low \\
\hline Girls & $11.66 \%$ & $55 \%$ & $33.33 \%$ \\
\hline Boys & $18.33 \%$ & $51.66 \%$ & $30 \%$ \\
\hline
\end{tabular}

Contingency Table No. 8 (Persuasive)

\begin{tabular}{|l|l|l|l|l|}
\hline Students & High & Moderate & Low & Total \\
\hline Girls & $7(9)$ & $33(32)$ & $20(19)$ & 60 \\
\hline Boys & $11(9)$ & $31(32)$ & $18(19)$ & 60 \\
\hline Total & 18 & 64 & 38 & 120 \\
\hline
\end{tabular}

$X^{2}=1.04:$ df. $=.2$

Significant at 0.05 level of confidence

Percentage Table No. 9(Social)

\begin{tabular}{|l|l|l|l|}
\hline Students & High & Moderate & Low \\
\hline Girls & $13.33 \%$ & $53.33 \%$ & $33.33 \%$ \\
\hline Boys & $28.33 \%$ & $40 \%$ & $31.66 \%$ \\
\hline
\end{tabular}

Contingency Table No, 9 (Social)

\begin{tabular}{|l|l|l|l|l|}
\hline Students & High & Moderate & Low & Total \\
\hline Girls & $8(12.5)$ & $32(28)$ & $20(19.5)$ & 60 \\
\hline Boys & $17(12.5)$ & $24(28)$ & $19(19.5)$ & 60 \\
\hline Total & 25 & 56 & 39 & 120 \\
\hline
\end{tabular}

$X^{2}=4.4: \mathrm{df}=2$

Significant at 0.05 level of confidence

Percentage Table No. 10 (Household)

\begin{tabular}{|l|l|l|l|}
\hline Students & High & Moderate & Low \\
\hline Girls & $\%$ & $38.33 \%$ & $61.66 \%$ \\
\hline Boys & $3.33 \%$ & $51.66 \%$ & $45 \%$ \\
\hline
\end{tabular}

Contingency Table No. 10 (Household)

\begin{tabular}{|l|l|l|l|l|}
\hline Students & High & Moderate & Low & Total \\
\hline Girls & $0(1)$ & $23(27)$ & $37(32)$ & 60 \\
\hline Boys & $2(1)$ & $31(27)$ & $27(32)$ & 60 \\
\hline Total & 2 & 54 & 64 & 120 \\
\hline
\end{tabular}

$X^{2}=4.74: \mathrm{df}=2$

Significant at 0.5 level of confidence 
Present Scenario Regarding Vocational Interest between the Genders
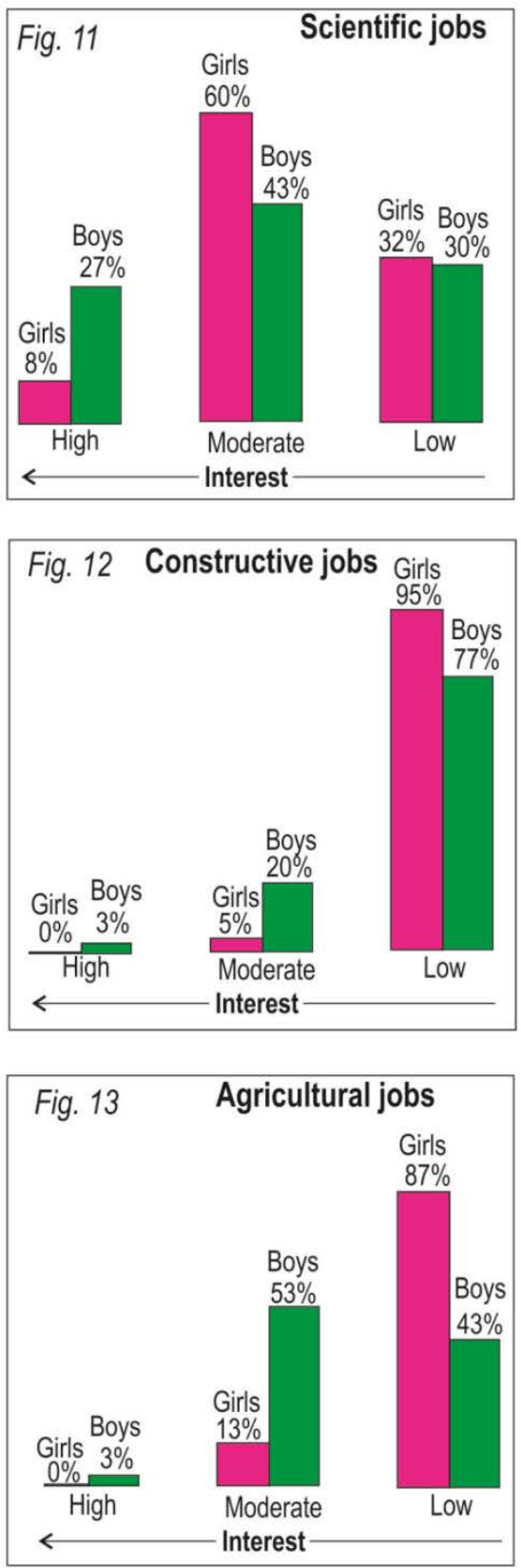

Figs. 11 to 13. Relative percentage of highly, moderately, and lowly interested boys and girls in scientific, constructive and agricultural jobs. 
Present Scenario Regarding Vocational Interest between the Genders
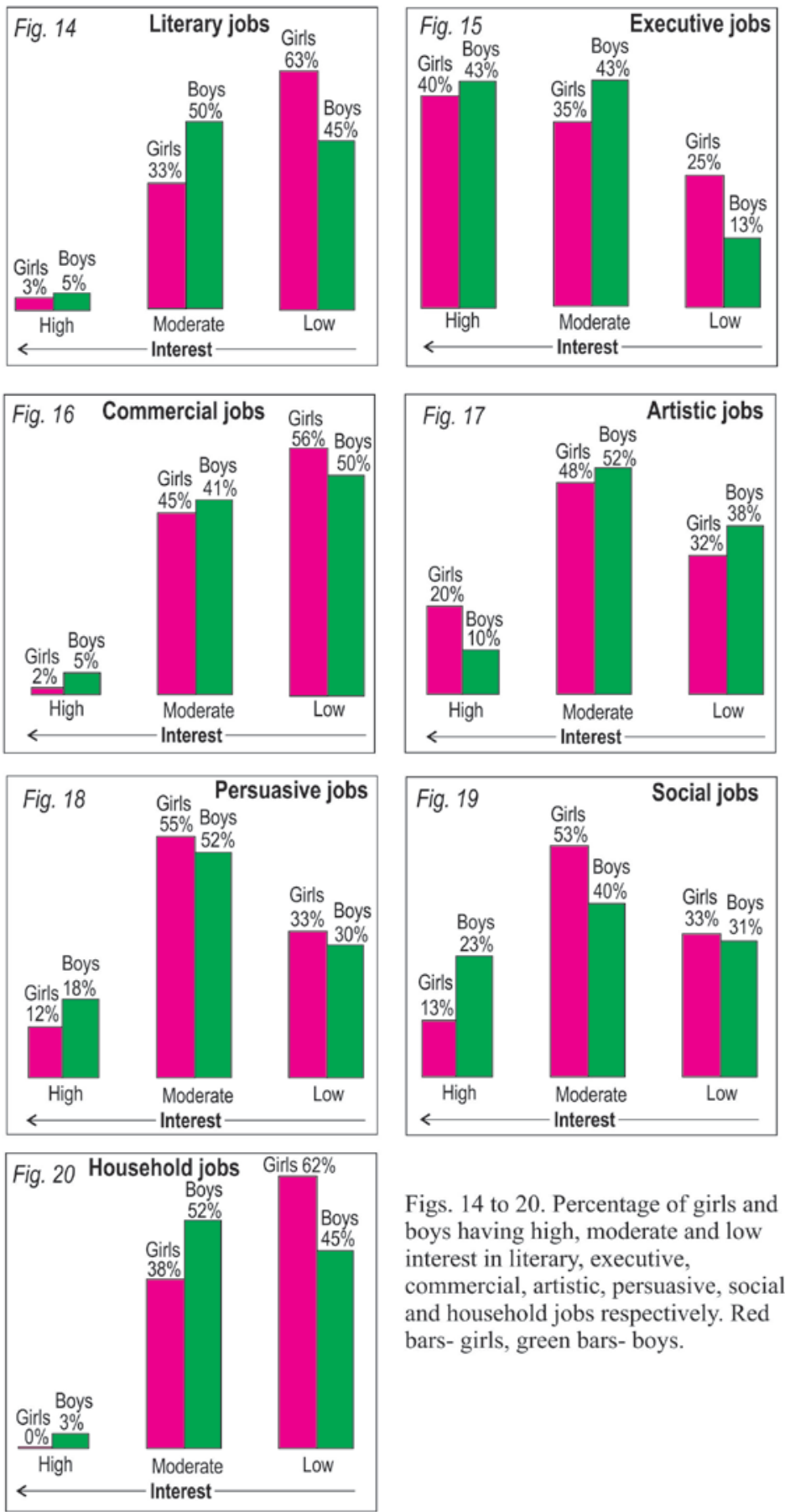

Figs. 14 to 20. Percentage of girls and boys having high, moderate and low interest in literary, executive, commercial, artistic, persuasive, social and household jobs respectively. Red bars- girls, green bars- boys.

\section{Acknowledgments}

The author appreciates all those who participated in the study and helped to facilitate the research process.

\section{Conflict of Interests}

The author declared no conflict of interests. 


\section{REFERENCES}

Bem SL. (1984). Adrogyny and gender schema theory: A Conceptual and empirical integration. In R.A.Dientsbier \& T.B.Sondregger(Eds.), Nebraska Symposium on motivation Vol. 34, pp.179-226.

Emmerich W. (1981). Non-Montonic development trends in social cognition. The case of gender constancy. In S. strauss (Ed), U-Shaped behavioral growth pp. 249-269 New York:

Hurlock EB. (2011). Developmental Psychology, fifth edition, Tata Mc Graw Hill Publishing Company Limited, New Delhi, ISBN-13: 978-0-07-099363-1, Page: 295 to 302

Kohlberg L. (1966), A cognitive development analysis of children's sex role concepts and attitudes. In E.E. Maccoby (Ed), pp. 82-173.

Kulshrestha SP. (1977). Vocational Interest Record. National Psychological corporation, Agra282004 (India).

Martin CL \& Little JK. (1990). The relation of gender understanding to children's sex-typed preferences and gender stereotypes. Child Development, 61, 1427-1439.

Papalia E.D., Olds.S.W., Feldman. R.D..(2004), "Human Developmen”,. Tata McGraw-Hill Education Private Limited, New Delhi, ISBN: 0-07-121501-8(ISE), Page: 273-280.

Srivastava A. (2015). Vocational interest of adolescents and early adults, Behavioural Scientist, ISSN:0972-5911, Vol. 16, No. 1., PP.51-60.

How to cite this article: A Srivastava (2016), Present Scenario Regarding Vocational Interest between the Genders, International Journal of Indian Psychology, Volume 4, Issue 1, No. 69, ISSN:2348-5396 (e), ISSN:2349-3429 (p), DIP:18.01.003/20160401, ISBN:978-1-365-45447-9 